\title{
Supernumerary epidermal shields and carapace variation in Orbigny's slider turtles, Trachemys dorbigni (Testudines, Emydidae)
}

\author{
Clóvis S. Bujes \& Laura Verrastro
}

Laboratório de Herpetologia, Departamento de Zoologia, Instituto de Biociências, Universidade Federal do Rio Grande do Sul. Avenida Bento Gonçalves 9500, Bloco IV, prédio 43.435, 91540-000 Porto Alegre, Rio Grande do Sul, Brasil.

E-mail: chelonia_rs@hotmail.com; lauraver@ufrgs.br

\begin{abstract}
The epidermal plates of the carapace and plastron of 51 adults (38 females and 13 males), 07 immature individuals, and 46 hatchlings of the freshwater turtle Trachemys dorbigni (Durémil 8 Bibron, 1835), originated from the delta of Rio Jacuí region, Rio Grande do Sul state, Brazil, were examined. The results showed that $7.7 \%$ of males, $10.52 \%$ of females, $14.28 \%$ of immature individuals, and $6.52 \%$ of the hatchlings presented a kind of anomaly on the shell, as well as a presence of supernumerary epidermal shields. Although the modification in the number of epidermal shields presents a high frequency in Testudines, these are the first descriptions of the variation in the pattern of carapacial scutation in eleven individuals from a population of $T$. dorbigni. The association of several environmental factors acting on the embryonic development of the individual may be responsible for the alteration of the pattern of carapacial scutation in this species.
\end{abstract}

KEY WORDS. Delta do Jacuí State Park; epidermal scutes; freshwater turtles; shell's anomaly.

RESUMO. Escudos epidérmicos supernumerários e variação na carapaça na tartaruga-tigre-d'água, Trachemys dorbigni (Testudines, Emydidae). Os escudos epidérmicos da carapaça e do plastrão de 51 adultos (38 fêmeas e 13 machos), 07 imaturos e 46 filhotes da tartaruga de água doce Trachemys dorbigni (Durémil \& Bibron, 1835), procedentes da região do delta do Rio Jacuí, Rio Grande do Sul, Brasil, foram examinados. Desta análise, 7,7\% dos machos, $10,52 \%$ das fêmeas, $14,28 \%$ dos imaturos e $6,52 \%$ dos filhotes apresentaram algum tipo de anomalia no casco, bem como presença de escudos epidérmicos supernumerários. Embora a alteração no número dos escudos epidérmicos seja relativamente freqüente em Testudines, estas são as primeiras descrições de variação no padrão de escutelação em onze indivíduos de uma população de $T$. dorbigni. A associação de diferentes fatores ambientais, interagindo sobre o desenvolvimento embrionário do indivíduo, parece ser a responsável pela alteração do padrão de escutelação nessa espécie.

PALAVRAS-CHAVE. Anomalias do casco; Parque Estadual Delta do Jacuí; tartarugas de água doce.

The development of supernumerary plates (additional shields) in chelonians is a relatively common phenomenon that has its origins in genetic anomalies or during the embryogenesis. COKER (1910) was the first author to question that these anomalies are a result of mutations in the embryogenesis, an idea that later on was supported by other investigators (LynN 1937, Lynn \& Ullrich 1950, Frye 1991).

The term carapacial scutation, introduced by Deraniyagala (1939), refers to a standardized carapace found in chelonians, which is composed by anterior and median shields (nuchal) and by a series of median longitudinal, non-paired plates: the vertebral shields. These structures are protected on each side by a series of shields that are paired bilaterally (coastal). The whole structure is bordered by a series of scutes that are also paired bilaterally (marginal). Supracaudal shields are located in the posterior region, among the last pairs of marginal shields.
Presence of additional or reduction in the number of shields apparently have no effect on the survivorship of individuals (EWERT 1979). Individual variation was observed in almost all turtles that present these dermal scutes (MAST \& CARR 1989).

Even though these supernumerary dermal shields are very common in Testudines (ESTRADEs 2002), these are the first records of such anomaly in freshwater chelonians of the species Trachemys dorbigni (Durémil \& Bibron, 1835).

Trachemys dorbigni is one of the most abundant freshwater turtles in Rio Grande do Sul state, Brazil. This species is locally known as "tartaruga-tigre-d'água" (in English: Orbigny's slider turtles), and, despite being endemic in Southern Brazil, several specimens can be found in other Brazilian states. Several individuals of $T$. dorbigni could reach a linear length of the carapace of twenty five centimeters. The shell (carapace and 
plastron) in this species is elliptical, high, dome-shaped, and composed by 38 horny shields: one nuchal, two supracaudal, 22 marginals, five vertebral, and eight costal shields, in the carapace, and by 16 horny shields: two gular, two humeral, two pectoral, two abdominal, two femoral, two anal, two axillaries, and two inguinal shields that form the plastron (CABRERA 1998). The arrangement and number of these shields are important for generic and specific determination of several chelonians.

The goal of the present study was to record and describe the occurrence of supernumerary dermal shields, as well as anomalies found on the shell of individuals of $T$. dorbigni, from a wild population.

\section{MATERIAL AND METHODS}

The study was carried out between March 2003 and April 2004. The animals were collected in a canal between Mauá and Pintada islands, inside the Delta do Jacuí State Park, Rio Grande do Sul, Brazil.

The Delta do Jacuí State Park was created by Decree number 18.161 , in January $14^{\text {th }}, 1976$. The park is located on the eastern side of Rio Grande do Sul state, Brazil, at a latitude of $29^{\circ} 53^{\prime}$ and $30^{\circ} 03^{\prime}$ South and a longitude of $51^{\circ} 28^{\prime}$ and $51^{\circ} 13^{\prime}$ West, occupying five municipalities in the metropolitan region of Porto Alegre city. The area has more than 21.000 hectares, and is formed by emerged continental land and 28 islands (Oliveira 2002). The humid areas of the delta of Jacuí River are vegetation complexes expanding throughout recent sedimentary deposition. Herbaceous species hygrophilous or hydrophytes, sessile or floating, are the dominant vegetation in this complex (Menegat et al. 1998).

Turtles investigated in the present study were collected from a wild population found in Mauá Canal (Fig. 1). Box traps (dimensions 600x360x800 mm), made out of wire and with bait inside, were semi-submerged and left in the water for a period of
24 hours. The traps were monitored every three hours for the presence of turtles. Samples were collected in a frequency of two to three consecutive days per week between September and January, and one day per week in the other months. Females that were laying eggs and hatchlings were collected by hand.

After collection, animals were weighted (adults were weighted in scales Spring Pesola ${ }^{\circledR} ; 1000 \mathrm{~g} / 25 \mathrm{~g}$, and hatchlings in a digital scale Giros ${ }^{\circledR} ; 500$ g/0.1 g) and measured. Measurements included: maximum linear length of the carapace (CL) and plastron (PL); maximum linear width of carapace (CW) and plastron (PW); and maximum linear height of the shell (HS). Collected specimens were freed in the sampling site after biometric data were obtained and photographs were taken.

Anomalies found on the shell were recorded. These records were based on a modified pattern (CABRERA 1998) of carapace and plastron established for this species (Figs 2 and 3).

The word "seam" and/or "seams" - referring to the limit between two dermal shields - used in the description followed AlHo et al. (1979).

\section{RESULTS}

A total of 51 adults (38 females and 13 males), seven juveniles (animals without secondary sexual characters) and 46 hatchlings originated from natural nests were captured and measured. Results showed that $7.7 \%$ of males, $10.52 \%$ of females, $14.28 \%$ of juveniles, and $6.52 \%$ of hatchlings presented one type of anomaly in the carapacial scutation, which is on the carapace, or plastron. Table I shows biometric data obtained for these animals. Below, we provide descriptions of the variation in the carapacial scutation found in the sampled turtles.

Td-001 (Fig. 4) - The specimen presented: six coastal dermal shields on the left, with the third and fourth shields divided in two; five costal shields on the right, with the fourth shield divided in two; eight vertebral shields, with the third

Table I. Morphological measurements of Orbigny's slider turtles (Trachemys dorbigni) collected in Mauá Canal, Delta do Jacuí State Park, Rio Grande do Sul, Brazil. (CL) Carapace length, (PL) plastron length, (CW) carapace width, (PW) plastron width, (HS) height of the shell - in millimeters, mass in grams.

\begin{tabular}{|c|c|c|c|c|c|c|c|}
\hline Code & Class & $\mathrm{CL}$ & PL & $\mathrm{CW}$ & PW & $\mathrm{HS}$ & Mass \\
\hline $\mathrm{Td}-001$ & male & 187.3 & 163.8 & 145.5 & 91.6 & 76.1 & 1400 \\
\hline Td-007 & juvenile & 165.1 & 157.2 & 132.5 & 84.4 & 73.4 & 700 \\
\hline Td-035 & female & 191.9 & 174.4 & 153.0 & 116.1 & 85.5 & 1050 \\
\hline Td-046 & female & 241.1 & 225.5 & 180.3 & 140.9 & 108.6 & 2200 \\
\hline Td-022 & female & 200.9 & 180.8 & 154.3 & 113.6 & 88.3 & 1300 \\
\hline Td-037 & female & 252.1 & 234.4 & 184.6 & 136.0 & 113.3 & 2500 \\
\hline Td-Re013 & hatchling & 33.8 & 33.5 & 32.3 & 21.8 & 16.6 & 8.8 \\
\hline Td-Re024 & hatchling & 33.9 & 33.6 & 32.6 & 21.8 & 16.9 & 8.6 \\
\hline Td-Re032 & hatchling & 35.6 & 34.1 & 32.5 & 23.8 & 17.6 & 9.2 \\
\hline Td-Re033 & hatchling & 38.6 & 37.0 & 36.7 & 24.1 & 17.7 & 10.8 \\
\hline Td-Re041 & hatchling & 34.8 & 34.0 & 32.1 & 21.1 & 17.2 & 9.0 \\
\hline
\end{tabular}




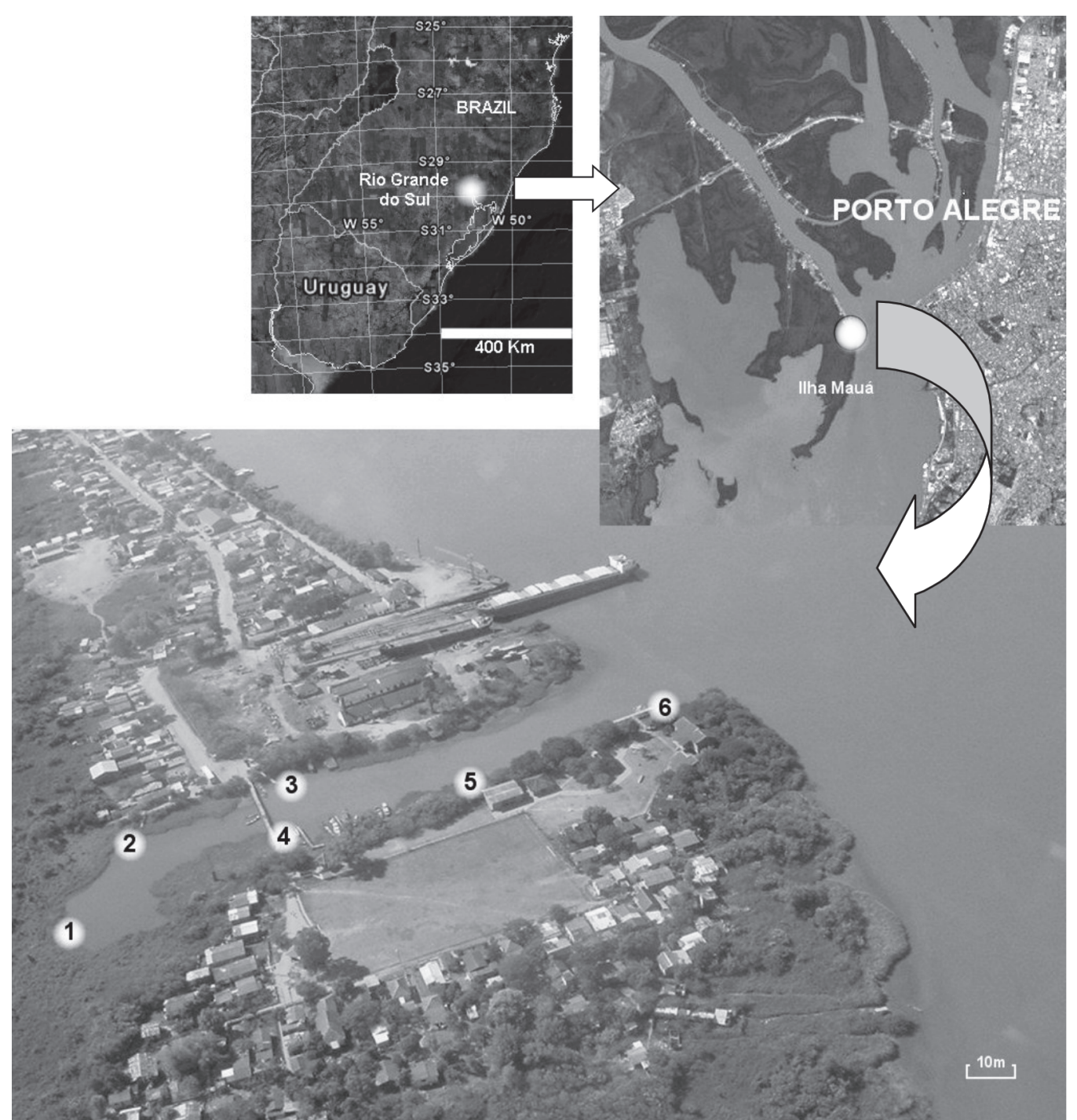

Figure 1. Geographical localization of the study area: Mauá Island, Porto Alegre, Rio Grande do Sul, Brazil. Numbers (1-6) indicate the stations where traps were placed in the canal.

divided in two, the fourth divided in three, and the fifth being larger than normal. Marginal shields and shields located in the plastron did not show any alteration.

Td-007 (Fig. 5). This specimen presented a supernumerary complex with: seven costal dermal shields on the left, with the first one reduced, and the second, third and fourth shields divided in two; five costal shields on the right, with the fifth shield divided in two; eight vertebral shields, with the second and third presenting a longitudinal division that split the shield and two, the fourth shield presenting a diagonal division, and the fifth being larger than the normal pattern for the species (Fig. 2). Marginal and plastron shields did not show any alteration.

Td-035 (Fig. 6). This female presented five costal shields on the right side, and the fourth coastal plate divided in two shields. Marginal and plastron shields did not show any alteration.

Td-046 (Fig. 7). This female presented five costal shields on the right, the second shield divided in two, and the third vertebral shield modified presenting a " $\mathrm{w}$ " shaped base overlying the fourth vertebral shield. Also presented a reentrance or absence of tissue on the fifth and sixth right marginal shields, and an invagination on the "seam" between the eighth and ninth right marginal shields. This "seam" separated completely the two shields. Plastron shields did not show any alteration.

Td-022 (Fig. 8). This specimen presented an extra shield overlying the "seams" of fourth and fifth vertebral shields and

Revista Brasileira de Zoologia 24 (3): 666-672, setembro 2007 

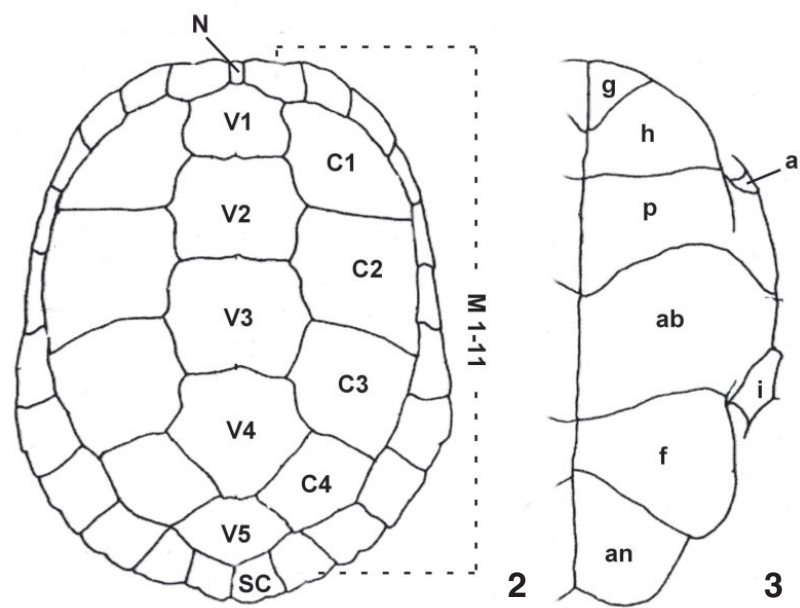

Figures 2-3. Pattern of epidermal shields of Trachemys dorbigni: (2) Carapace scutes: (N) nucal (1), (V) vertebral (1-5), (C) costal (1-4, both sides), (M) marginal (1-11, both sides), and (SC) supracaudal (1, both sides); (3) Plastron scutes: ( $g$ ) gular, (h) humeral, ( $p$ ) pectoral, (ab) abdominal, (f) femoral, (an) anal, (a) axillary, and (i) inguinal (all paired). $\mathrm{CL}=180 \mathrm{~mm} ; \mathrm{PL}=159 \mathrm{~mm}$.

fourth costal shield on the left. It also presented a deep scar process starting on the second costal shield (represented by dots in figure 10), passing the sixth marginal shield on the right and the bridge region, and reaching the plastron region. In the plastron, this process occupied almost $50 \%$ of the abdominal shield on the left, reaching the pectoral border on the left side, and a small portion of the left femoral shield. The right pectoral shield presented a section (represented by horizontal lines in the same figure) that starts on the posterior border of the humeral, almost reaching the "seam" between the pectoral and abdominal shields.

Td-037 (Fig. 9). This specimen presented six vertebral shields resulting from the longitudinal division of the fifth vertebral shield. It also presented cuts on the carapace, one of them over the "seam" between the third and forth left marginal shields. The other one divided totally the $10^{\text {th }}$ right marginal shield, crossing the "seam" between that shield and the fourth right costal. Two other cuts were observed on the plastron: one on the left pectoral shield and the other one on the border of the right humeral shield. In figure 9 , these cuts (absence of dermal or bony tissues) were represented by horizontal lines.

Td-Re013 (Fig. 10). Specimen with five left costal shields, and with the forth shield divided. Presence of six vertebral shields: first and second shields modified, originating a third shield. Marginal shields and the ones on the plastron were not modified.

Td-Re024 (Fig. 11). Individual presenting seven right costal shields; eight left costal shields, and nine vertebral shields. Vertebral shields 1-3 and 5 (in this supernumerary series) showed a larger width in comparison with the scute formation pattern (Figs 2 and 3). The vertebral shield number five of the standardized carapacial scutation pattern seems to be divided in three or four scutes. Marginal and plastron shields did not show any alteration.

Td-Re032 (Fig. 12). This specimen presented six vertebral shields. The first one was divided, and the third presented a basal elongation invaginating over the fourth shield. This invagination resulted in a fourth shield with a " $U$ " shape. Marginal and plastron shields did not present any alteration.

Td-Re033 (Fig. 13). The carapace of this juvenile presented an " $\mathrm{H}$ " shaped area rich in melanin (black pigmentation; region bordered by a dotted line in figure 13) on the "seam" of marginal shields $4-7$, on the right costal shields 1-3; on the "seam" between right costal shields 2-3; and on the "seams" between right costal shields 1-3 and vertebral 2-4. The other shields on the carapace and plastron did not present alteration.

Td-Re041 (Fig. 14). Six right costal shields: shield number 3 divided in three shields. Seven vertebral shields, with numbers 4 and 5 divided in two. Marginal and plastron shields were not modified.

\section{DISCUSSION}

During the development of the research focusing biology and conservation of chelonians in the Delta do Jacuí State Park it was observed that some animals had different kinds of injuries on their shells. These injuries were mainly related to the human action, such as, hit by a car, fire, injuries caused by machinery in rice plantations, or by helices from boats. Injuries recorded in specimens Td-022 (scar process) and in the individuals Td-037 and Td-046 resulted from mechanic action. Burn injuries, as observed in an animal coming from another study area, were different from those found in the present study. Although most of the time the animal survives, the fire could destroy total or partially the epidermal layer of the shell, damaging and exposing the bony tissue (KUCHLING 1997).

Variation in the carapace shields in Trachemys dorbigni probably does not affect the development of the individuals, as suggested by GADOW (1899); however this variation does not change during the development of the hatchlings, in the adult life or during senescence, as pointed out by the same author. Results from the present work demonstrated that adult males and females presented these supernumerary shields and at the same time were in good reproductive activity.

GADOw (1899) investigating the species Caretta caretta (Linnaeus 1758) pointed out that adults presented less variation in the carapace shields than juveniles. Therefore, he suggested that juvenile turtles that presented more shields than the standard for the species, would suffer fusion of these shields during ontogeny, resulting in a reduced but normal pattern of shields in adulthood. NeWMAN (1906), on the other hand, suggested that supernumerary shields were a result of reappearance of shields that disappeared during phylogeny, that is, a result of non-expression of one or more genes in one or more generations. 

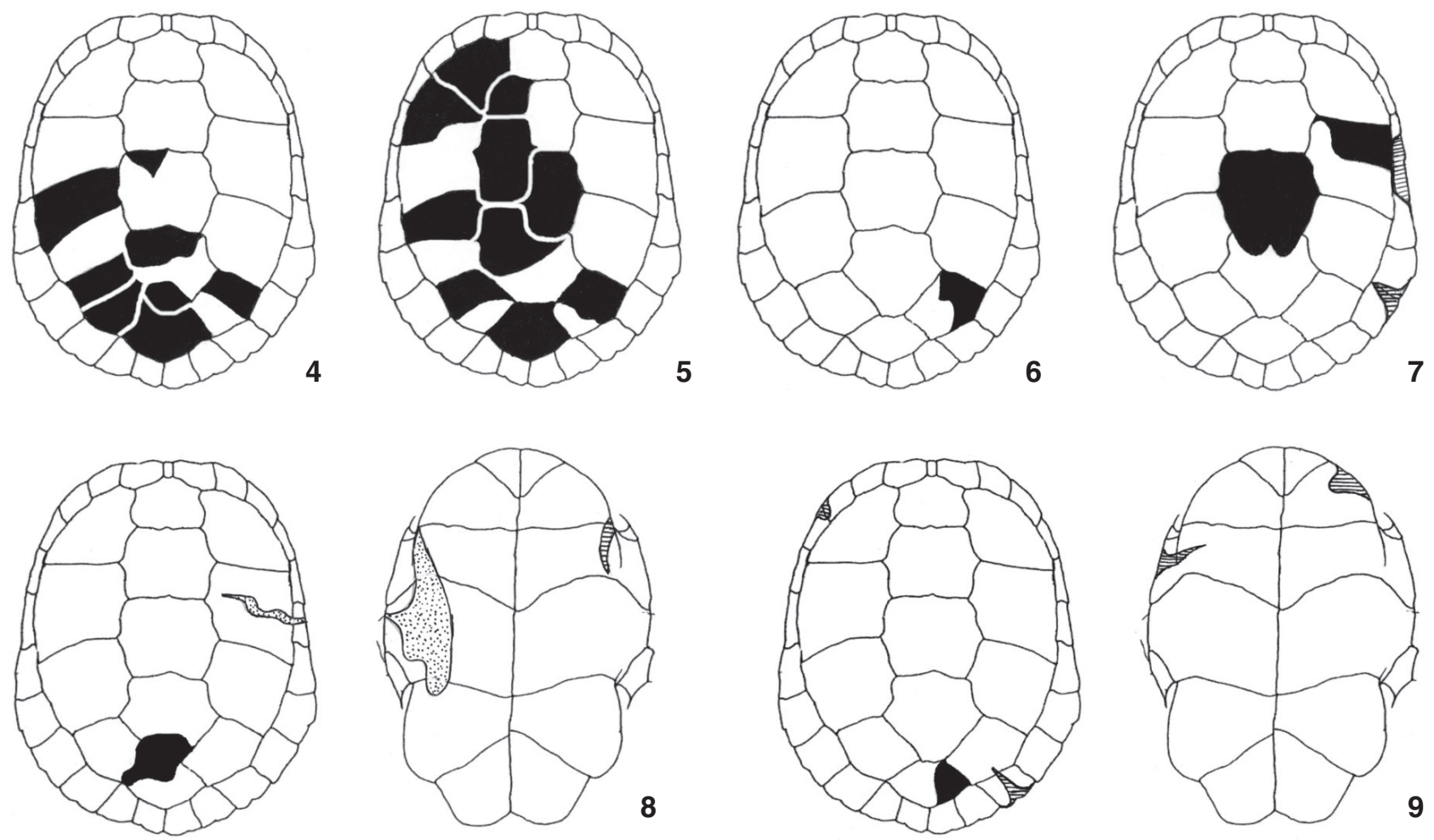

Figures 4-9. Representation of the carapace of specimens: (4) Td-001, (5) Td-007, (6) Td-035, and (7) Td-046, and of the carapace and plastron of the individuals (8) Td-022, and (9) Td-037 of the species Trachemys dorbigni. Black areas show supernumerary epidermal scutes, crossed areas the absence of tissue (shell deformation), and dotted areas represent scar processes (see individual measurements on table I).
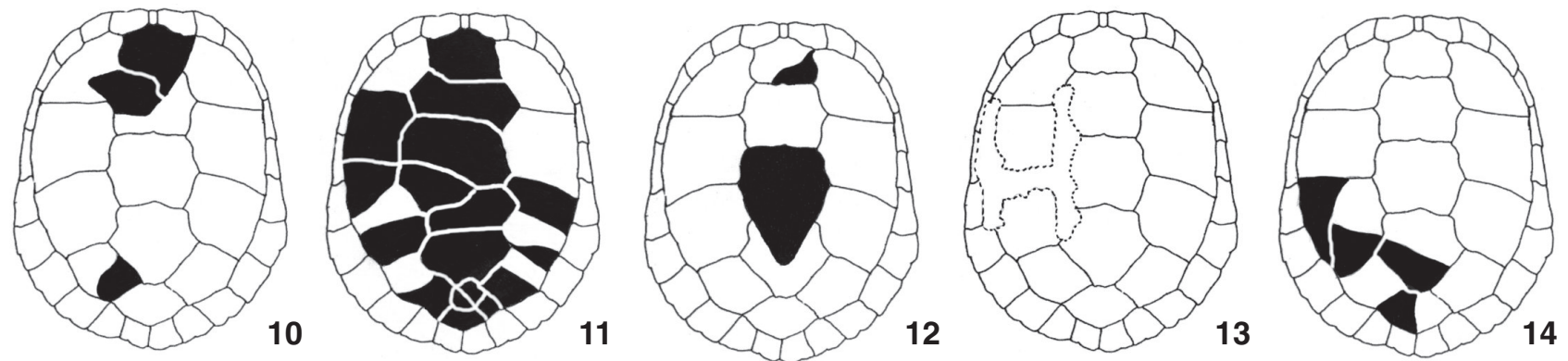

Figure 10-14. Representation of the shell of hatchlings of the species Trachemys dorbigni after leaving natural nests: (10) Td-Re013, (11) Td-Re024, (12) Td-Re032, (13) Td-Re033, and (14) Td-Re041. Black areas show supernumerary epidermal scutes, and the dotted line borders an anomaly with absence of epidermal shields (see individual measurements on table I).

Parker (1901), Hildebrend (1930) and Zangerl (1969) suggested that anomalies in carapacial scutation were a result of accidents or dysfunctions during ontogeny.

Among these dysfunctions, HiLDEBREND (1938) pointed out the variation in the supply of oxygen during egg incubation as a probably cause of anomalies present in the carapace shields of Malaclemys terrapin (Schoepff 1793).
Variation of nest temperature during incubation was also suggested as responsible for the abnormal carapacial scutation in Chelydra serpentina (Linnaeus 1758) (YNTEMA 1976), and in Caretta caretta (YnTEMA \& Mrosovsky 1980). YnTEMA \& Mrosovsky (1980, 1982), investigating sexual determination influenced by temperature in C. caretta, suggested that morphogenetic effects may occur in turtles with a variable response to the tempera- 
ture. Rate of carapace alteration in juveniles of Chelonia mydas (Linnaeus 1758) incubated artificially was higher than in juveniles originated from nests (Suganuma et al. 1994). On the other hand, C.S. Bujes (personal observation) did not observe in juveniles of T. dorbigni, originated from artificial incubation, an atypical carapacial scutation pattern.

MAST \& CARR (1989) suggested that handling of eggs after oviposition could have a strong effect on the variation of carapace shields. Handling of eggs during embryonary development, in addition to induce embryo mortality (Limpus et al. 1979), may also be responsible for the shield variation in Lepidochelys olivacea (Eschscholtz, 1829) (HILl 1971). At first, we considered that the handling effect may have contributed to the occurrence of supernumerary plates in $6.52 \%$ of the hatchlings of $T$. dorbigni in the present study, since all eggs in natural incubation nests were handled by the first author to obtain biometric data. However, according to EWERT (1979), standardized carapacial scutation may also have a critical period in the differentiation, as observed for gonad differentiation in chelonians, that occurs around the third half of the incubation time (YnTema \& Mrosovsky 1982). Since handling of eggs of $T$. dorbigni occurred right after oviposition, we rejected the hypothesis that handling would be responsible for the occurrence of supernumerary plates in hatchlings.

As proposed by ÖZDEmír \& TÜrKozAN (2006), we agree that not only one factor would be responsible for the occurrence of supernumerary plates in chelonians, but different environmental factors associated, acting on the development of the individual and influencing in the variation of carapacial scutation pattern during incubation.

\section{ACKNOWLEDGMENTS}

This work was partially financed by Fundação O Boticário de Proteção à Natureza (FBPN, Projeto Chelonia-RS registry 0594-20032); we had logistic support from the Instituto Gaúcho de Estudos Ambientais (INGA), from the Secretaria Estadual do Meio Ambiente (SEMA), and from the Departamento de Zoologia da Universidade Federal do Rio Grande do Sul (UFRGS). We thank the employees of the Delta do Jacuí State Park for their special collaboration in the present study.

\section{REFERENCES}

Alho, C.J., A.G. Carvalho \& L.F. PÁduA. 1979. Ecología de la tortuga de la Amazonía y evaluación de su manejo en la Reserva Biológica del Río Trombetas. Brasil Florestal 9 (38): 29-47.

Cabrera, M.R. 1998. Las tortugas continentales de Sudamerica Austral. Buenos Aires, Ediciones Independentes, 108p.

COKER, R.E. 1910. Diversity in the scutes of Chelonia. Journal of Morphology 21 (1): 1-75.

Deraniyagala, P.E.P. 1939. The tetrapod reptiles of Ceylon. I. Testudines and Crocodilians. Colombo Museum, Colombo, Ceylon. In: B. Özdemír \& O. Türkozan. 2006. Carapacial scute variation in Green Turtle, Chelonia mydas hatchlings in Northern Cyprus. Turkish Journal of Zoology 30: 141-146.

Estrades, A. 2002. Primeras observaciones de placas dérmicas supernumerárias para Chelonia mydas (Testudines, Cheloniidae) en Uruguay. Boletín de la Sociedad Zoológica del Uruguay 13: 25-28.

Ewert, M.A. 1979. The embryo and its egg: development and natural history, p. 333-413. In: M. Harless \& H. Morlock (Eds). Turtles, perpectives and research. New York, John Wiley \& Sons, 695p.

FrYe, F.L. 1991. Biomedical and surgical aspects of captive reptile husbandry. Malabar, Krieger Publisher, 637p.

GADOw, H. 1899. Orthogenetic variation in the shells of Chelonia. Willey's Zoological Results 3:207-222. In: W.G. LYNN \& M.C. UlLRICH. 1950. Experimental production of shell anomalies in turtles. Copeia 1950 (4): 253-262.

Hildebrend, S.F. 1930. Duplicity and other abnormalities in diamondback terrapins. Journal of the Elisha Mitchell Scientific Society 46: 41-53.

Hildebrend, S.F. 1938. Twinning in Turtles. Journal of Heredity 29: 243-253.

HiLL, R.L. 1971. Surinam turtle notes - 1. Polymorphism of costal and vertebral laminae in the sea turtle Lepidochelys olivacea. Stichting Natuurbehoud Suriname (Stinasu), Mededelingen 2:1-9.

Kuchling, G. 1997. Restoration of epidermal scute patterns during regeneration of the chelonian carapace. Chelonian Conservation and Biology 2: 500-506.

Limpus, C.J.; V. BAKer \& J.D. Miller. 1979. Movement induced mortality of loggerhead eggs. Herpetologica 35: 335-338.

LyNN, W.G. 1937. Variation in scutes and plates in the box-turtle Terrapene carolina. American Naturalist 71 (735): 421-426.

LyNN, W.G. \& M.C. UlLRiCh. 1950. Experimental production of shell anomalies in turtles. Copeia 1950 (4): 253-262.

Mast, B.R. \& J.L. Carr. 1989. Carapacial scute variation in Kemp's Ridley Sea Turtle (Lepidochelys kempii) hatchlings and juveniles. Conservation and Management 202-219.

Menegat, R., M.L. Porto, C.C. Carraro \& L.A.D. Fernandes. 1998. Atlas Ambiental de Porto Alegre. Porto Alegre, Universidade Federal do Rio Grande do Sul, Prefeitura Municipal de Porto Alegre, Instituto Nacional de Pesquisas Espaciais, EDUFRGS, p. 21-59.

Newman, H.H. 1906. The significance of scute and plate "abnormalities" in Chelonia. Biological Bulletin 10: 68-114.

Oliveira, M.L.A.A. 2002. Conhecendo o Parque. In: Natureza em Revista, Edição Especial: Delta do Jacuí. Porto Alegre, Fundação Zoobotânica do Estado do Rio Grande do Sul, p. 20-23.

Özdemír, B. \& O. Türkozan. 2006. Carapacial scute variation in Green Turtle, Chelonia mydas hatchlings in Northern Cyprus. Turkish Journal of Zoology 30: 141-146.

PARKER, G.H. 1901. Correlated abnormalities in the scutes any bony plates of the carapace of the sculptured tortoise. 
American Naturalist 35: 17-24.

Suganuma, H.; K. Horikoshi \& H. TachiKana. 1994. Scute deviation of green turtle hatchlings from a hatchery in Ogasawara Islands, Japan. Sea Turtle Biology and Conservation 1994: 148.

YNTEMA, C.L. 1976. Effects of incubation temperatures on sexual differentiation in the turtle, Chelydra serpentina. Journal of Morphology 150: 453-462.

Received in 05.VI.2007; accepted in 14.VIII.2007.
YnTema, C.L. \& N. Mrosovsky. 1980. Sexual differentiation in hatchling loggerhead (Caretta caretta) incubated at different controlled temperatures. Herpetologica 36: 33-36.

YNTEMA, C.L. \& N. Mrosovsky. 1982. Critical periods and pivotal temperatures for sexual differentiation in loggerhead sea turtles. Canadian Journal of Zoology 60: 1012-1016.

ZANGERL, R. 1969. The turtle shell, p. 311-339. In: C. GANs (Ed.). Biology of Reptilia: morphology. London, vol. 1, 373p. 